\title{
Pola Interaksi dan Komunikasi Kyai terhadap Santri di Pesantren Sirnarasa
}

\author{
Ahmad Ramdan ${ }^{1}$ Maman Usman ${ }^{2}$. \\ ${ }^{1}$ Universitas Islam Negri Sunan Gunung Djati, Bandung, Indonesia. \\ ramdan@stidsirnarasa.ac.id. \\ STID Sirnarasa, Ciamis, Indonsesia.
}

\begin{abstract}
ABSTRAK
Pola interasksi merupakan suatu cara, model, dan bentuk-bentuk interaksi yang saling memberikan pengaruh dan mempengaruhi dengan adanya timpal balik guna mencapi tujuan. Penelitian bertujuan untuk mengetahui pola interaksi dan komunikasi Kiyai terhadap Santri di Pesantren Sirnarasa. Metode penelitian deskriptif kualitatif. Teknik penelitian yang dilakukan dengan cara observasi, wawancara, dan studi kepustakaan. Data yang diperoleh, kemudian dianalisis dengan beberapa tahapan, yaitu mengumpulkan data tentang pola interaksi dan komunikasi, pengaruh, dan faktor pendukung dan penghambatnya, kemudian diklasifikasikan serta dihubungkan antara satu dengan yang lainnya, untuk menghasilkan suatu kesimpulan. Data yang ditemukan menunjukan bahwa pola interaksi dan komunikasi Kiyai terhadap santri di Pesantren Sirnarasa, sudah terbentuk secara aktif. Pola yang diterapkan oleh Muhammad Abdul Gaos Saefulloh Maslul terhadap santrinya adalah pola komunikasi verbal, intruksional, personal dan intrapersonal. Dalam hal ini, Kiyai dan Santri berperan sebagai komunikator dan komunikan. Kedekatan antara keduanya semakin intens ketika interaksi sosial mulai diterapkan. Dan pengaruh interaksi dan komunikasi kyai terhadap santri di pesantren sirnarasa sangat terasa. Santri mulai mengikuti prilaku kyainya sehingga tercermin akhlak yang baik. Hasilnya santri dapat berkomunikasi dengan baik dan benar kepada semua orang, akhlak santri
\end{abstract}


semakin meningkat yang ditandai dengan sikap khidmat, dan ta'dzim kepada Kiyai beserta keluarga besar Pesantren Sirnarasa, dan santri semakin memahami dan mematuhi peraturan-peraturan sebagaimana yang telah diterapkan oleh Pesantren Sirnarasa sehingga kegiatan rutinitas santri Pesantren Sirnarasa terkoordinir dengan baik, walaupun terdapat faktor penghambatnya, namun dapat diatasi dengan baik pula.

Kata kunci : Pola; Interaksi; Komunikasi;

\section{ABSTRACT}

The interactional pattern is a way, model, and form of interaction that affects each other and influences with the presence of reverse timpal to melt objectives. The research aims to determine the pattern of Kiyai's interaction and communication towards Santri in Pesantren Sirnarasa. Qualitative descriptive research methods. Research techniques conducted by means of observation, interviews, and literature studies. Data obtained, then analyzed by several stages, namely collecting data on the interaction and communication patterns, influences, and contributing factors and the termination, then classified and connected to each other, To make a conclusion. The Data found showed that Kiyai's interaction and communication patterns against students at Pesantren Sirnarasa, have been actively formed. The pattern applied by Muhammad Abdul Gaos Saefulloh Maslul against the Santrinya is a verbal, instrusional, personal and intrapersonal communication pattern. In this case, Kiyai and Santri acted as communicators and communfishes. The proximity between the two is increasingly intense when social interactions begin to apply. And the influence of interaction and communication of the students in the students Pesantren Sirnarasa very pronounced. Santri started to follow his behavior so it is reflected good morality. The results of the students can communicate well and correctly to all people, students are increasingly increasing the marked with reverent attitude, and Ta'dzim to Kiyai and the family of Pesantren Sirnarasa, and students increasingly understand and obey Regulations that have been applied by Pesantren Sirnarasa so that the activity of the students of Pesantren Sirnarasa is well coordinated, although there is a factor of the termination, but it can be solved well too.

Keywords : pattern; interaction; communication; 


\section{PENDAHULUAN}

Pendahuluan Pola fikir manusia akan ada batasan dalam setiap memahami upaya memebentuk karakteristik dirinya, namun semua itu bisa terbuka dengan pancaran cayaha akan ke Esaan Allah SWT. Pikiran positive, ketentraman jiwa dan keikhlasan hati dalam menempuh hubungan baik dengan seseorang yang kita anggap sebagai orang yang mampuh merubah kehidupan sehingga akan menghasilkan kepribadian budi utama jasmani sempurna (cageur bageur) (Tanbih:1956).

Dalam persepektif agama, interaksi dan komunikasi sangat penting peranannya dalam kehidupan manusia bersosialisasi, manusia dituntut agar pandai dalam berinteraksi dan komunikasi. Karakteristik manusia akan mulai terbentuk apabaila interaksi mulai ditumbuh kembangkan dengan seseorang yang dijadikan sebagai patron (suri teladan), sehingga akan muncul sikap berani dan terbiasa dalam berkomunkasi melalui bimbingan secara emosional, intelektual dan spiritual (riadhoh).

Dimensi kehidupan manusia sangatlah berbeda antara yang satu dengan yang lainnya, keaneka ragaman pengalaman dan pola hidup manusia sangat unik sehingga akan banyak menimbulkan kontropersi, namun semua itu hanya keaneka ragaman displin ilmu yang mereka miliki. Allah berfirman dalam QS. Al Hujjuraat ayat 10 surat 49 juz 26:

Orang-orang beriman itu sesungguhnya bersaudara. Sebab itu damaikanlah (perbaikilah hubungan) antara kedua saudaramu itu dan takutlah terhadap Allah, supaya kamu mendapat rahmat.

Perlu disadari bahwa peran interaksi dan komunikasi tidak hanya terbatas pada kegiatan bersosialisasi saja, bahkan proses belajar mengajarpun sangat memerlukan interaksi dan komunikasi. Karena proses belajar mengajar pun pada hakekatnya adalah proses penyampaian pesan berupa ilmu melalui komunikator (guru) kepada komunikan (santri). Pesan yag disampaikan berisikan materi-materi pelajaran yang ada dalam kurikulum. Sumber pesan dapat berposisi 
sebagai guru, murid, dan lain sebagainya. Sedangkan salurannya berupa media pendidikan dan penerimanya adalah santri (Alisuf Sabri, 2005: 11).

Fungsi komunikasi tidak hanya sebagai pertukaran informasi dan pesan, tetapi juga sebagai kegiatan individu dan kelmpok mengenai tukar menukar data, fakta, dan ide. Agar komunikasi berlangsung efektif dan informasi yang hendak disampaikan oleh seorang kyai dapat diterima dengan baik oleh santri, maka seorang kyai dituntut untuk dapat menerapkan pola interaksi dan komunikasi yang baik pula. Pesantren sesuai dengan fungsinya sebagai lembaga pendidikan tradisional, tempat untuk mempelajari, mendalami, menghayati, dan mengamalkan ajaran agama Islam yang menerapkan pentingnya moral keagamaan.

Kyai dalam suatu Pesantren merupakan elemen yang penting. Sudah sewajarnya perkembangan pesantren semata-mata bergantung pada kepribadian kyai-nya. Di sebuah pesantren, kyai adalah salah satu yang menjadi faktor pemicu minat santri dalam mendalami ilmu agama. Dalam hal pembelajaran, kyai mempunyai peranan penting pula dalam membentuk sikap dan kepribadian para santri baik dalam tata pergaulan maupun kehidupan bermasyarakat. Untuk mencapai itu semua dibutuhkan terciptanya sebuah suasana interaksi dan komunikasi yang baik antara kyai dan santri-nya.

Dewasa ini penyebab dari pergaulan yang tidak terkontrol interaksi antara kyai dan santri mulai ada kesenjangan meneyebabkan banyak informasi yang diterima tidak tepat sasaran sehingga menimbulkan kontroversi. Keaneka ragaman sistem komunikasi santri sangat unik apabila setiap manusia menelaah kehidupan mereka baik dari segi ekonomi, logat ( bahasa ), gaya hidup ( life style ), pola makan dan pola belajar. Tak aneh apabila seorang santri dengan life style nya menjadikan seseorang yang non santri menganggap kampungan melihat hal tersebut.

Namun dari hal itu kehidupan santri bisa menjulang tinggi dengan disiplin ilmu yang mereka miliki, sehingga akan membawa kehidupan masyarakat lebih cenderung dengan pendidikan pesantren, munculah 
A Ramdan, M. Usman.

pendidikan pesantren modern yang sangat beraneka ragam dengan pola pendidikan kepesantrenan yang digabungkan denga pendidikan formal.

Pesantren merupakan lembaga pendidikan yang memberikan kekhasan dalam sistem interaksi dan komunikasi kyai-santri sehingga dapat membedakan dengan lembaga pendidikan lainnya. Hubungan yang dibentuk antara kyai dengan santri adalah bentuk hubungan guru-murid yang terlihat dalam hubungan bapak-anak dan juga patron klien (Rochidin, 2004: 153-154).

Kiyai sebagai bapak agama adalah bapak bagi santri yang mempunyai kedudukan lebih mulia daripada bapak biologis, sebab bapak agama mengangkat santri ke alam yang abadi (malakut). Sedangkan bapak biologis hanya menurunkan santri ke alam yang fana. Kyai sebagai patron (teladan), adalah kyai yang mampu membangun sebuah patronase dengan santrinya melalui ikatan lahir bathin yang kuat.

Patron memberikan jasa kepada santri baik pengetahuan, material dan harapan barakah serta ilmu bermanfaat. Dalam konteks kesantrian tidak ada harga yang mampu ditebus untuk mengukur segala pengetahuan yang diberikan oleh kyainya. Oleh sebab itu, santri sebagai klien harus memperlihatkan tanda-tanda ketadhiman terhadap Kiyainya.

Pembentukan ketadhiman santri terhadap Kiyai dibentuk seiring penancapan doktrin-doktrin ketadhiman dan kewibawaan kharismatik Kiyai sebagai orang sholeh dan suci yang mampu menyalurkan barokah dan kualat. Kedua hal tersebut dibentuk oleh tradisi lisan cerita yang beredar atau sedikit mengalami pengalaman gaib yang di sangkut pautkan dengan keampuhan kyai.

Pada akhirnya terbentuklah pandangan "pengakuan santri", bahwa kyainya adalah orang yang luar biasa dan mereka tidak salah tempat mencari orang untuk berguru. Muara yang terbentuk adalah simbolsimbol cinta, pengidolaan, dan penauladanan yang tercermin dalam sikap dan perilaku santri terhadap kyainya.

Dalam hal ini penulis menanggapi bahwa dalam interaksi dan komunikasi antara kyai dan santri untuk menumbuhkan sikap dan 
akhlak yanga mulia diperlukan pendekatan yang intens sehingga tidak akan menimbulkan kesalah fahaman dalam menyampaikan informasi atau ajakan. Upaya dalam menyampaikan informasi kepada komunikan maka kyai menggunakan komunikasi personal, intrapersonala, verbal dan nonverbal.

Namun dari hal komunikasi tersebut menimbulkan permasalahan bagi santri itu sendiri, dikarenakan tidak memahami secara penuh apa yang disampaikan kyai maka terjadi miss comunication (salah menanggapi pembicaraan), disamping hal tersebut santri tidak begitu memahami bagaimana cara menerima atau memnyampaikan informasi yang baik dan benar. Metode yang digunakan dalam penelitian ini adalah metode deskriptif kualitatif yaitu metode yang bertujuan untuk melukiskan secara sistematik keberadaan populasi atau sampel secara faktual dan cermat

\section{LANDASAN TEORITIS}

Sebagai mahluk sosial, manusia dalam kehidupan sehari-hari membutuhkan hubungan dengan manusia yang lain. Hubungan tersebut terjadi karena manusia saling membutuhkan untuk dapat memenuhi kebutuhannya. Karena manusia tidak bisa lepas dari manusia lainnya dan tidak bisa melakukan seorang diri. Kecenderungan manusia berhubungan melahirkan komunikasi dengan manusia yang lainnya. Komunikasi terjadi karena saling membutuhkan melalui sebuah interaksi. Interaksi merupakan hubungan antarmanusia yang sifat dari hubungan tersebut adalah dinamis artinya hubungan itu tidak statis, selalu mengalami dinamika ( Setiadi,Elly M. 2011,h. 62).

Hubungan antara manusia satu dan lainnya disebut interaksi. Dari interaksi akan menghasilkan produk-produk interaksi, yaitu tata pergaulan yang berupa nilai dan norma yang berupa kebaikan dan keburukan dalam ukuran kelompok tersebut. Pandangan tentang apa yang dianggap baik dan apa yang dianggap buruk tersebut mempengaruhi perilaku sehari-hari (Setiadi,Elly M. 2011,h.38). 
A Ramdan, M. Usman.

Interaksi adalah proses dimana orang-orang berkomunikasi saling memengaruhi dalam pikiran dan tindakan. Seperti kita ketahui, bahwa manusia dalam kehidupan sehari-hari tidaklah lepas dari hubungan satu dengan yang lain. Ada beberapa pengertian interaksi sosial yang ada di lingkungan masyarakat, di antaranya; Menurut $H$. Booner dalam bukunya, Sosial Psychology, memberikan rumusan interaksi sosial, bahwa: "interaksi sosial adalah hubungan antara dua individu atau lebih, dimana kelakuan individu yang satu memengaruhi, mengubah, atau memperbaiki kelakuan individu lain atau sebaliknya." Menurut Gillin and Gillin yang menyatakan bahwa "interaksi sosial adalah hubunganhubungan antara orang-orang secara individual. Antarkelompok orang, dan orang perorang dengan kelompok" (Setiadi,Elly M. 2011,h.90-91).

Dengan demikian pada dasarnya, interaksi ialah hubungan antar inividu, kelompok, dimana dengan adanya hubungan itu dapat saling mempengaruhi, merubah baik dari yang buruk menjadi lebih baik atau sebaliknya. Dalam kamus bahasa Indonesia, pola adalah "gambar, corak, model, sistem, cara kerja, bentuk, dan struktur". Sedangkan interaksi artinya hal yang saling melakukan aksi, berhubungan, memengaruhi, dan antar hubungan (Kamus Besar Bahasa Indonesia, h,1088).

Menurut Soerjono Soekanto (2001), interaksi sosial adalah hubunganhubungan sosial yang dinamis yang menyangkut hubungan antar orangperorang, antara kelompok-kelompok manusia, maupun antara orang perorangan dengan kelompok manusia. Interaksi sosial merupakan syarat utama terjadinya aktivitas-aktivitas sosial. Berlangsungnya suatu proses interaksi sosial didasarkan pada pelbagai faktor antara lain, faktor imitasi, sugesti, identifikasi dan simpati.

Apabila kata tersebut dikaitkan dengan interaksi maka dapat diartikan pola interaksi adalah bentuk dasar cara komunikasi individu dengan individu atau individu dengan kelompok atau kelompok dengan individu dengan memberikan timbal balik antara pihak satu dengan yang lain dengan maksud atau hal-hal tertentu guna mencapai tujuan.

Dalam Kamus lengkap Bahasa Indonesia, M. Ali menyatakan bahwa pola adalah gambar yang dibuat contoh /model. Jika dihubungkan dengan 
pola interaksi adalah bentuk-bentuk dalam proses terjadinya interaksi. Interaksi yang bernilai pendidikan dalam dunia pendidikan ataupun yang disebut dengan interaksi edukatif, sebagai contoh dari pola interaksi adalah dalam hal seorang guru menghadapi murid-muridnya yang merupakan suatu kelompok manusia di dalam kelas. Di dalam interaksi tersebut pada taraf pertama akan tampak bahwa guru mencoba untuk menguasai kelasnya supaya proses interaksi berlangsung dengan seimbang, di mana terjadi saling pengaruh-mempengaruhi antara kedua belah pihak. Sebagai contoh lain seorang guru mengadakan diskusi diantara anak didiknya untuk memecahkan sebuah persoalan, disinilah proses interaksi itu akan terjadi, adanya saling memberikan pendapat yang berbeda satu sama lain.

Dapat disimpulkan bahwa pola interasksi merupakan suatu cara, model, dan bentuk-bentuk interaksi yang saling memberikan pengaruh dan mempengaruhi dengan adanya timpal balik guna mencapi tujuan. Guru sebagai pengajar memiliki peran penting utuk dapat mengatur jalannya kegiatan belajar mengajar melalui pola interaksi dimana guru berperan sebagai pemberi aksi melalui pengajaran dan juga bisa menjadi penerima aksi melalui pertanyaan-pertayaan yang diajukan oleh siswa. Sebaliknya siswa pun memiliki peran yang sama dengan guru bisa sebagai pemberi aksi melalui melalui pertanyaan-pertayaan yang diajukan olehnya dan juga bisa menjadi menjadi penerima aksi melaui belajar dan mendengarkan. Namun, kerjasama dapat sangat membantu dalam proses kegiatan belajar mengajar yang diperlukan oleh guru dan siswa.

\section{HASIL DAN PEMBAHASAN}

Hasil Dari penjelasan KH. Muhammad Ucu Syamsudin terhadap ayat tersebut kalau kita belum mengetahui sesuatu maka kita di sarankan untuk bertanya kepada orang yang lebih tau, agar kita lebih paham dan tidak salah paham atau salah pengertian. Hal tersebut dapat diketahui dari adanya manajemen interaksi yang baik, dimana keduanya yaitu kyai dan santri saling memberikan kesempatan untuk berbicara sehingga percakapan yang terjadi antara keduanya terus mengalir. 
A Ramdan, M. Usman.

Kiyai memberikan kesempatan kepada santri untuk bertanya dengan harapan agar kyai sendiri tahu apakah pesan yang disampaikan diterima secara baik atau tidak. Dari itu dapat diketahui bahwa komunikan juga memiliki peranan yang sama dengan komunikator. Muhammad Ucu Syamsudin Hasan, selaku pengisi materi, bahwa memberikan kesempatan kepada santri untuk berbicara, juga merupakan proses belajar agar santri memiliki mental dan berani berbicara di depan forum serta untuk mengetahui sejauh mana santri paham akan materi yang telah kyai berikan. Jadi dapat dijadikan sebagai tolak ukur peningkatan pemahaam agama santri. Dengan adanya sikap terbuka dan saling timbal balik dalam memberikan serta menerima pelajaran antara kyai dan santri maka tingkat pemahaman agama santri akan lebih meningkan atau santri akan semakin paham.

Sebagaimana penuturan Bapak Sambas pada saat penulis berdiskusi bahwa sikap empati harus dimiliki oleh seorang Kiyai dalam kegiatan belajar mengajar sehigga bisa melihat situasi dan kondisi santri pada saat itu. Kiyai memberikan kesempatan kepada santri untuk menayakan apa yag belum santri pahami, dengan tujuan agar santri yang belum paham menjadi paham dan yang sudah paham menjadi lebih paham.

Disaat suasana kelas sedang tidak enak, santri tidak konsen atau serius dalam menerima pelajaran maka kyai memberikan sedikit humor agar suasana kelas menjadi lebih menyenangkan dan santri tidak merasa tegang denganmkeadaan. Walaupun demikian santri selalu menerima pelajaran dari Kiyai dengan senang hati dan serius demi peningkatan pengetahuan pemahaman agama mereka. Disini santri juga bisa merasakan seandainya mereka menjadi Kiyai, bagaimana apabia mereka menyampaikan materi tidak didengarkan dengan serius.

Seorang Kiyai tidak boleh memaksakan santrinya untuk bisa secara langsung memahami ilmu yang diberikannya karena memerlukan beberapa tahapan diantaranya sebagai berikut: a) Dalam menyampaikan materi Kiyai harus memberikan sesuai kemampuan santri dalam memahami isi materi. B) Berikan waktu kepada santri untuk membaca ulang materi yang diberikan. C) Situasi ketika memberikan materi harus 
dalam keadaan tenang. D) Tempat untuk memeberikan materi tidak boleh sembarang tempat.

Di Pesantren Sirnarasa semua santri diajarkan latihan ceramah atau pidato yang juga bertujuan agar santri bisa meraskan menjadi penceramah seperti Kiyai yang membutuhkan pendengar. Dari kegiatan inilah santri paham akan pentignya keseriusan dalam mendengarkan serta memahami materi yang disampaikan oleh Kiyai demi peningkatan pemahaman ilmu agama snatri itu sendiri.

Dalam upaya meningkatkan mutu santri Pesantren Sirnarasa, Kiyai dan santri harus saling mendukung sehingga tercipta komunikasi intrapersonal yang baik. Kyai mempunyai tujuan untuk mentransfer ilmu pengetahuan agama yang dimilikinya kepada santri, agar tingkat pemahaman santri tentang agama bertambah atau meningkat.

Sedangkan santri bertujuan untuk mendapatkan ilmu pengetahuan agama dari kyai dan agar santri pun semakin paham. Dengan demikian dalam kegiatan belajar mengajar di Pesantren Sirnarasa berjalan dengan lancar, kedekatan intrapersonal antara Kiyai dan santri pun terlihat jelas. Dalam berkomunikasi antara Kiyai dan santri tidak terlihat adanya kecanggungan. Hal ini membuat proses belajar mengajar menjadi lebih nyaman.

Sikap positif yang diterapkan oleh Kiyai kepada santri mempunyai tujuan agar belajar mengajar Pesntren Sirnarasa berjalan dengan lancar agar visi dan misi Pesnatren Sirnarasa terwujud. Disaat Kiyai menegur santri yang melakukan kesalahan santri tidak marah dan menerima teguran serta nasehat kyai, sikap positif juga tunjukan oleh kyai kepada santri dalam menjalani roda kehidupan kyai di lingkungan masyarakat. Ketika Kyai mendapat cibiran atau hinaan dari warga setempat, kyai tetap tenang dan bersabar dalam menghadpainya bahkan Kiyai selalu mendoakannya supaya enjadi orang yang baik dan sholeh.

Menurut salah seorang santri senior Pesantren Sirnarasa yang sempat di wawancarai 5 Juni 2015, peran kyai sebagai pendidik dalam era globalisasi yang berlangsung saat ini sangat penting diharapkan dapat 
A Ramdan, M. Usman.

menghasilkan santri yang memiliki dedikasi tinggi, pantang menyerah dan peranan kyai yang sanggup menjadi dinamisator, motivator, inovator, katalisator dan juga tahu jati dirinya, serta betul-betul memiliki kompetensi baik profesional pribadi maupun kompetensi sosial. Bahwa semua santri yang ada dalam lingkungan pesantren Sirnarasa menjadi tanggung jawab kyai selaku pemimpin Pesantren yang dibantu oleh dewan kyai dan pengurus.

Dengan demikian seorang kyai atau pemimpin merupakan barisan terdepan yang memberikan bimbingan pengalaman langsung dalam mengembangkan kemampuan profesional dan perilaku yang harus dimiliki oleh santri sebagai calon kyai atau ustad dimasa yang akan datang. Oleh sebab itu komunikasi interpersonal kyai berperan sangat penting dan epektif dalam kegiatan belajar mengajar di dalam Pesantren, serta berperan aktif dalam mempengaruhi tingkat pemahaman santri.

Interaksi yang efektif sangat diperlukan dalam usaha peningkatan kemampuan seorang kyai dalam menyampaikan materi pembelajaran kepada santri. Hubungan yang komunikatif dapat terjadi karena kemampuan untuk memahami apa dan bagaimana persepsi seorang santri terhadap seorang kyai. Kegagalan berinteraksi sering disebabkan oleh kesulitan untuk mengerti dan memahami apa yang ada diantara kyai dan santri saat melakukan interaksi maupun komunikasi. Ada banyak hal yang mempengaruhi prestasi belajar santri, dan ada diantaranya adalah interaksi.

Dilihat dari pengamatan sementara, komunikasi santri pada saat kegiatan proses belajar berlangsung, kurangnya kepercayaan diri, kurangnya motivasi belajar dari dalam diri santri. Sedangkan interaksi yang ada Pesantren Sirnarasa meliputi metode mengajar, penyampaian materi, respon santri, efisiensi waktu. Dengan demikian, diharapkan komunikasi dan interaksi harus saling mendukung serta dapat meningkatkan komunikasi dan interaksi santri demi tercapainya prestasi belajar ilmu Agama yang maksimal.

Perlu diketahui bahwa, kewajiban menuntut ilmu bagi muslim laki-laki dan perempuan ini tidak untuk sembarang ilmu, tapi terbatas pada ilmu 
agama, dan ilmu yang menerangnkan cara yang bertingkah laku atau bermuamalah dengan sesama manusia. Sehingga ada yang berkata, "Ilmu yang paling utama adalah ilmu Hal dan perbuatan yang paling mulia adalah menjaga perilaku", yang dimaksud ilmu hal ialah agama Islam, sholat misalnya.

Karena sesuatu yang menjadi perantara untuk melakukan kewajiban, maka mempelajari wasilah atau perantara tersebut hukumnya wajib. Ilmu agama adalah wasilah untuk mengerjakan kewajiban agama maka, mempelajari ilmu agama itu hukumnya wajib. Misalnya ilmu tentang puasa, zakat, haji dan ilmu tetang jual beli.

Belajarlah ilmu agama, karena ia adalah ilmu yang paling unggul. Ilmu yang dapat membimbing dalam kebaikan dan taqwa, ilmu untuk dipelajari dan diamalkan. Dialah ilmu yang menunjukan pada jalan yang lurus, yakni jalan petunjuk. Ia laksana benteng yang dapat menyelamatkan manusia dari segala keresahan. Oleh karena itu orang yang ahli ilmu agama dan bersifat wara' lebih berat bagi setan dari pada menggoda seribu orang ahli ibadah tapi bodoh.

Proses interaksi dan komunikasi yang terjadi dalam kegiatan belajar mengajar merupakan salah satu bentuk kegiatan komunikasi kelompok kecil, indikasi ini terlihat ketika komunikator meyampaikan pesannya kepada komunikan yang berjumlah lebih dari tiga orang atau lebih. Meskipun komunikasi antara kyai dan santri dalam kelas tersebut termasuk komunikasi kelompok kecil, sang kyai bisa mengubahnya menjadi komunikasi intrapersonal (antarpribadi) dengan menggunakan metode komunikasi dua arah atau dialog, yakni kyai menjadi komunikator dan santri menjadi komunikan.

Terjadi komunikasi dua arah ini ialah apabila para santri bersifat responsif, mengetengahkan pendapat atau mengajukan pertanyaan diminta atau tidak diminta. Jika si santri pasif saja, atau hanya mendengarkan tanpa adanya gairah atau tanggapan untuk mengekpresikan suatu pernyataan atau pertanyaan, komunikasi itu tetap 
A Ramdan, M. Usman.

bersifat tatap muka, dan komunikasi itu berlangsung satu arah serta tidak efektif dalam proses belajar mengajar.

Dalam mencetak para santri agar dapat menguasai materi yang disampaikan kyai sesuai dengan ilmu-ilmu agama. KH. Muhammad Abdul Gaos Saefulloh Maslul menerapkan metode-metode pengajaran dalam menyampaikan materi atau pesan kepada santri untuk mempermudah memahami materi atau pesan tersebut. Adapun metodemetode yang digunakannya, adalah sebagai berikut:

Pertama Metode tanya jawab adalah penyampaian pembelajaran dengan cara kyai mengajukan pertanyaan dan siswa menjawabnya atau sebaliknya. Seorang kyai manyampaikan materi kepada santri secara langsung melalui tatap muka dengan lisan dan menggunakan komunikasi kelompok kecil, setelah santri mendengarkan materi tersebut dengan baik, maka kyai mempersilahkan kepada santri yang hendak bertanya apabila materi yang dijelaskan belum dapat dimengerti dan dipahami. Maka kyai akan menjawab pertanyaan-pertanyaan yang diajukan oleh santri dengan baik.

Kedua Metode peraga atau yang disebut komunikasi nonverbal merupakan bentuk penyampaian pesan atau materi dengan cara mempraktekkan atau memperagakan barang, kejadian, aturan dan urutan melakukan sesuatu kegiatan baik secara langsung maupun melalui penggunaan media komunikasi relevan dengan materi yang sedang disajikan.

Metode ini sangat merangsang santri untuk lebih aktif dalam mengikuti proses pembelajaran di Pesantren, dengan menggunakan komunikasi nonverbal dalam arti memeperkuat apa yang dibicarakan dapat membantu santri untuk mengingat lebih lama materi pelajaran yang telah disampaikan, karena santri tidak hanya mendengar tetapi juga melihat peragaan kyai secara langsung dalam berkomunikasi.

Metode ini akan berjalan lebih efektif dan efisien, apabila materi yang diperagakan dan ditindaklanjuti oleh santri dalam kehidupan sehari-hari maupun latihan secara continue sehingga santri tidak lupa dengan materi 
tersebut. Dengan penggunaan metode ini, kyai mudah mengukur dan menilai kemampuan dalam memahami ilmu agama. Sehingga dengan adanya metode dan materi yang sudah disebutkan di atas tersebut, dapat mempermudah kyai dalam menyampaikan pesan (materi) kepada para santrinya. Dan santripun dapat dengan mudah untuk memahaminya.

Dengan demikian menurut penulis proses belajar-mengajar yang diterapkan oleh kyai dalam menyampaikan sebuah materi atau pesannya, sudah bisa dikatakan cukup baik. Hal ini disebabkan materi yang akan disampaikan sudah terencana atau dirancang sedemikian rupa.

Setelah penulis melihat pola komunikasi yang berlangsung dalam kegiatan belajar mengajar di Pesantren Sirarasa, antara kyai dan santri sudah melakukan pola komunikasi yang sangat epektif dan episien untuk melangsungkan kegiatan tersebut, walaupun terdapat beberapa hambatan hambatan yang sering terjadi pada diri santri, misalnya hambatan dari lingkungan tempat tinggal santri, dan psikologi yang dialami santri.

Dikatakan pola komunikasi tersebut berjalan dengan efektif, indikasi ini dilihat pada proses penyampaian (teori), dimana hal tersebut terjadi ketika seorang guru menyampaikan sebuah materi. Dan sebelum menyampaikan materi, kyai terlebih dulu merencanakan pesan (materi pelajaran) yang akan disampaikan kepada santrinya, dengan pesan-pesan yang terancana, sehingga menimbulkan suatu komunikasi yang baik dan mudah dimengerti oleh seorang santri. Pada hal lain, dikatakan komunikasi yang baik jika seorang kyai dan santri mengadakan kesamaan makna atau arti.

Dikatakan efesien, indikasi ini terjadi pada proses pembelajaran atau praktek, ketika terdapat beberapa santri yang belum mengerti, disebabkan santri tersebut kurang memahami dasar-dasar atau basik pada suatu materi yang berlangsung. Oleh sebab itu, seorang kyai memerintahkan kepada santri yang sudah mengerti untuk memberitahu atau menerangkan kepada santri yang belum paham. Dengan begitu proses kegiatan belajar-mengajar menjadi sangat efesien. 
A Ramdan, M. Usman.

Setiap pelajar menata niatnya ketika akan belajar. Karena niat adalah pokok dari segala amal ibadah. Nabi bersabda, "Sesungguhnya amal itu tergantung pada niatnya"

Niat seorang santri dalam menuntut ilmu harus ikhlas mengharap ridho Allah, mencari kebahagiaan diakhirat menghilangkan kebodohan dirinya, dan orang lain menghidupkan agama, dan melestarikan islam. Karena islam akan tetap lestari kalau pemeluknya atau umatnya berilmu. Zuhud dan taqwa tidak sah tanpa disertai ilmu. Syaikh Burhanuddin menukil perkataan para ulama` berikut : “Orang yang tekun beribadah tapi bodoh, bahayanya lebih besar dari pada orang alim tapi durhaka. Keduanya adalah penyebab fitnah dikalangan umat, yaitu bagi orang yang menjadikan mereka sebagai panutan dalam urusan agama

Dalam menuntut ilmu harus didasari niat untuk mensyukuri nikmat akal dan kesehatan badan. Jangan sampai terbesit niat supaya dihormati masyarakat, untuk mendapatkan harta dunia (wawancara: salah seorang santri Sirnarasa, 6 Juni 2015).

Tradisi santri Pesantren Siirnarasa, perasaan hormat dan kepatuhan murid kepada gurunya adalah mutlak dan tidak boleh putus, artinya berlaku seumur hidup simurid. Disamping itu rasa hormatnya yang mutlak itu harus ditunjukkan dalam seluruh aspek kehidupannya, baik dalam kehidupan keagamaan, kemasyarakatan, maupun pribadi. Melupakan ikatan dengan guru dianggap sebagai suatu aib besar, disamping akan menghilangkan barakah guru.

Dalam hal ini penulis memperhatikan tingkah laku santri Pesantren Sirnarasa yang hendak berniat menuntut ilmu, selalu berkomunikasi kepada kyainya atasa keberlangsungan niatnya itu, namun kebiasaan santri dalam berkomunikasi terhadap kyai menggunakan komunikasi verbal, namun timbalbalik kyai terhadap santrinya pun dengan menggunakan komunikasi verbal pula.

Komunikasi verbal yang digunakan santri Pesantren Sirnarasa kepada kyaninya ternya memberikan epek baik bagi sanatri tersebut, dengan menggunakan komunikasi verbal santri lebih mudah memahami apa 
yang disampaikan kyai sehingga tercipta hubungan yang baik antara santri dan kyai di Pesantren Sirnarasa.

"Meraka yang mencari pengetahuan hendaklah selalu ingat bahwa mereka tidak akan pernah mendapatkan pengetahuan atau pengetahuannya tidak akan berguna, kecuali kalau ia menaruh hormat kepada pengetahuan tersebut dan juga menaruh hormat kepada guru yang mengajarkannya. Hormat kepada guru bukan hanya sekedar patuh. Sebagaimana dikatakan oleh Sayyidina 'Ali, "Saya ini hamba dari orang yang mengajar saya, walaupun hanya satu kata saja." (Az-Zarnuji,2009, h.60).

Sikap santri yang menunjukan hormat dan kepatuhan mutlak kepada kyainya, bukan sebagai manifestasi dari penyerahan total kepada kyai yang dianggap memiliki otoritas, tetapi karena keyakinan santri kepada kedudukan kyai sebagai penyalur kemurahan Tuhan yang dilimpahkan kepada muridmuridnya, baik di dunia maupun di akhirat.

Dalam ajaran islam, seorang murid harus menganggap kyainya seolaholah sebagai ayahnya sendiri. Dalam hal tersebut penulisa berpendapat bahwa kedekatan santri dengan kyai diawali dengan komunikasi verbal yang dilakukannya, sehingga akan tercipta interaksi dan komunikasi yang intens antara santri dan kyai. Seperti halnya yang dilakukan oleh santri Pesantren Sirnarasa ketika melangsungkan niat dalam mencari ilmu.

\section{Pengaruh Interaksi dan komunikasi Kyai Dalam Pembentukan Akhlak Santri Pesantren Sirnarasa}

Pola komunikasi intrapersonal memepunyai efek yang berlainan pada hubungan interpersonal. Tidak benar anggapan bahwa makin sering orang melakukan hubungan interpersonal dengan oranglain. Makin baik pula hubungn mereka. Yang jadi soal bukanlah berapa kali komunikasi dilakukan, tetapi bagaimana komunikasi interpersonal itu dilakukan dengan baik. Ada beberapa faktor agar komunikasi interpersonal dapat berjalan dengan baik, yaitu: "percaya (trust), sikap memberi dukungan (suportif), dan sikap terbuka. 
A Ramdan, M. Usman.

Faktor percaya adalah yag paling penting dalam komunikasi interpersonal. ada tiga faktor yang berhubungan dengan sifat percaya:

1). Percaya (trust)

Karakteristik dan kemampuan kyai akan menaruh kepercayaan kepda santrinya yang dianggap memiliki kemampua, keterampilan atau pengalaman dibidang tertentu.

Hubungan kekuasaan, kepercayaan santri tumbuh apabila kyai mempunyai kekuasaan terhadap orang lain, dan mampu mengendalikan permasalahan permasalahan yang timbul didalamnya.

Sifat dan kualitas komunikasi kyai, bila komunikasi bersifat terbuka, bila maksud dan tujuan sudah jelas, bila keberkahan sudah dinyatakan, maka akan timbul sikap percaya dalam jiwa santri.

2). Sikap memberi dukungan (suportif). Sikap suportif merupakan sikap yang mengurangi sikap defensive dalam komunikasi. Orang bersikap defensive bila ia tidak menerima, tidak jujur dan tidak empati terhadap apa yang mereka komunkasikan.

3). Sikap terbuka. Suatu komunikasi akan berhasil apabila adanya sikap terbuka antara komunikan dan komunikator mengenai masalah masalah yang mereka hadapi, karena dengan adanya sikap terbuka inilah akan diketahui solusi dalam menyelesaikan masalah yang dihadapi.

Menurut David Berlo dalam The Proses Of Communication menekankan bahwa diantara komunikator dengan komunikan harus terdapat hubungan interdependensi (Jalaludin Rakhmat 2000:126).

Interdependensi adalah "kedua belah pihak terdapat hubungan saling mempengaruhi". Menurut Nuruddin, interdependensi artinya "komponen-komponen itu saling berkaitan, berinteraksi dan berinterdependensi secara keseluruhan" (Nuruddin 2004:5-6).

Oleh sebab itu, seorang kyai dalam berkomunikasi tidak boleh melihat pada kepentingannya sendiri tapi juga harus melihat pada kepentingan dan kebutuhan santrinya dengan memperhatikan pengalaman, kepentingan dan pendapatnya serta menciptakan hubungan yang akrab. 
Dari definisi-definisi tersebut diketahui bahwa, nilai akhlak merupakan suatu hal yang abstrak, yang digunakan seseorang untuk memberikan tanggapan atau persepsi terhadap tingkah laku manusia, baik itu terhadap tingkah laku yang baik ataupun yang buruk, yakni dengan memberikan tanggapan bahwa tingkah laku seseorang itu baik ataupun buruk.

Nilai merupakan reaksi yang diberikan oleh manusia sebagai pemberi nilai. Berkaitan dengan pembahasan akhlak, nilai dapat digunakan sebagai tolak ukur dalam menentukan apakah perbuatan seorang itu baik ataupun buruk. Hal ini dikarenakan akhlak merupakan bagian dari ajaran Islam yang berkaitan dengan perbuatan dan tingkah laku manusia.

Dalam hal ini peran seorang kyai dalam melaksanakan interaksinya dengan santri merupakan suatu peranan penting guna untuk mengetahui latar belakang santri sehingga sang kyai dapat dengan mudah memeberikan pengarahan dalam upaya penerapan akhlak yang terpuji.

Proses komunikasi yang terjadi dalam kegiatan pembinaan akhlak merupakan salah satu bentuk kegiatan komunikasi kelompok kecil indikasi ini terlihat ketika komunikator meyampaikan pesannya kepada komunikan yang berjumlah lebih dari tiga orang atau lebih kemudian komunikator menunjukan pesannya berupa bentuk pikiran bukan perasaan komunikan.

Dalam hal ini setelah komunikator menyampaikan pesannya kepada komunikan maka timbulah beberapa pertanyaan yang diajukan oleh komunikan ketika mereka tidak paham mengenai hal-hal yang disampaikan komunikator dan ketika itu komunikator bisa merubah bentuk komunikasi tersebut dengan komunikasi interpersonal. Hal inilah yang menjadi pembeda antara Pesantren Sirnarasa dengan Pesantren yang ada disekitar Kecamatan Panjalu Ciamis. Dengan adanya program pembinaan akhlak yang ada di Pesantren Sirnarasa, sangat diharapkan oleh para Orang tua /wali Santri khususnya dalam pembinaan dan penerapan akhlakul karimah. 
A Ramdan, M. Usman.

Program pembinaan akhlak mulai diterapkan sejak santri akan daftar menjadi calon santri di Pesantren Sirnarasa, karena santri yang memiliki akhlak kurang baik kemungkinan besar tidak akan bisa diterima di Pesantren Sirnarasa, melainkan akan diarahkan ke Rehabilitasi Inabah yang sudah disediakan jauh jauh hari oleh Abah Anom, meskipun nilai kepribadiannya dulu bisa dikatakan kurang baik baik tapi kalau seandainya mau mengikuti aturan atu proses kegiatan Pesantren Sirnarasa maka akhlaknya sedikit demi sedikit akan ada perubahan yang signifikan.

Begitu pula dengan Santri yang sudah menjalani belajar di Pesantren Sirnarasa ini, bila memang akhlaknya tidak baik maka dari pihak Pesantren Sirnarasa tidak akan segan-segan untuk memberinya sanksi bahkan bisa pula dikeluarkan dari Pesantren Sirnarasa walaupun ia pandai. Dalam pembinaan akhlak Santri Pesantren Sirnarasa selaku Sesepuh Pesantren Sirnarasa sering kali menggunakan pendekatan komunikasi verbal.

\section{Pola komunikasi kyai terhadap santri di Pesantren Sirnarasa}

Proses pembelajaran akan mencapai tingkat keberhasilan yang maksimal bila didukung dengan hubungan komunikasi yang baik antara Kiyai dan santri. Pesantren adalah lembaga pendidikan yang mayoritas memberikan kajian mengenai ilmu agama secara mendalam.

Begitu pula dengan Pesantren Sirnarasa mengemas pendidikan dalam sistem pendidikan formal dan nonformal, dengan tujuan agar para santri dapat mendalami berbagai ilmu agama dan ilmu umum. Dengan didukung oleh tingkat spiritual yang tinggi, pengetahuan dan wawasan yang luas dan berakhlakul karimah yang kuat.

Berikut adalah beberapa program pendidikan Pesantren dalam proses belajar mengajar yang dilaksanakan oleh Pesantren Sirnarasa, di antaranya adalah:

Pola pengajaran yang dilakukan dalam program pengkajian kitab kuning di Pesantren ini adalah proses pemberian materi kepada para santri secara keseluruhan secara bersama-sama mendengarkan ketika seorang ustadz 
atau Kiyai membaca, menerjemahkan, menerangkan, dan mengulas secara mendalam sebuah pembina seni baca al-Qur'an. Setelah itu berlangsung, saatnya berganti posisi dengan ustadz atau kyai mendengarkan para santri yang membaca kitab yang telah dibahas oleh sang kyai. Dan setelah kedua kegiatan tersebut berlangsung, saatnya kyai menyuruh para santri untuk menghafalkan tiap-tiap bait kitab yang telah dibahas tadi untuk mendapatkan tingkat pemahaman yang mencukupi.

Pola komunikasi yang dilakukan dalam program ini yaitu dengan menggunakan pola komunikasi kelompok kecil yang dilakukan adalah menggunakan metode ceramah, kyai bertatap muka dengan sejumlah santri secara langsung dan membahas bait demi bait yang tedapat dalam kitab tersebut.

Memang sangat cocok dengan pola seperti itu, karena santri memang mengharapkan agar seorang kyai atau ustadz memberikan pengetahuan ilmu agamanya dengan kitab kuning sebagai kajiannya. Selain itu, Kiyai juga menggunakan pola komunikasi instruksional dengan memberi perintah kepada para santri untuk menghafal beberapa bait yang telah dibahas secara bersama-sama. Hal ini dapat menambah keilmuan santri dalam segi wawasan dan pengetahuan ilmu agama bagi diri mereka masing-masing.

Muhadatsah merupakan latihan berbicara atau bercakap-cakap dengan menggunakan bahasa Arab. Program ini dapat melatih keterampilan dan kemampuan para santri untuk berbicara dalam bahasa Arab sama halnya ketika mereka berbicara menggunakan bahasa Indonesia. Bila dilihat secara langsung, pola komunikasi yang dilakukan oleh pengajar program ini adalah pola komunikasi antar pribadi, komunikasi kelompok, dan komunikasi instruksional yang bertujuan untuk menumbuhkan rasa percaya diri mereka untuk berani mengungkapkan kata-kata dalam bahasa arab. Pola ini akan membiasakan para santri untuk dapat berbicara dan berkomunikasi dengan bahasa arab.

Pelaksanaan dalam program muhadatsah yaitu dengan mengumpulkan para santri di sebuah lapangan di pagi hari, mereka dipasangkan dengan 
seorang temannya untuk melaksanakan percakapan yang sudah mereka pelajari sebelumnya di rumah dalam bahasa Arab selama 15 menit. Setelah itu mereka dibariskan membentuk sebuah lingkaran dengan pengajar berada di tengah-tengah mereka, kemudian pengajar tersebut menunjuk salah seorang di antara para santri bergantian untuk bercakapcakap antara kyai dan santri selama 15 menit pula.

Dan dalam waktu 15 menit setelahnya, Kiyai memilih beberapa orang santri untuk tampil di hadapan teman-temannya untuk melakukan percakapan dalam bahasa Arab. Di sinilah pola instruksional memiliki peran agar mereka (santri) memiliki keberanian dalam berucap dengan bahasa Arab untuk dirinya sendiri atau dihadapan orang lain.

Muhadharah adalah suatu kegiatan latihan secara individual bagi para santri yang intinya bertujuan untuk melatih keterampilan mereka dalam berpidato. Sama halnya dengan program muhadatsah, program muhadarah ini menggunakan pola komunikasi kelompok dengan kyai memberikan penjelasan materi di hadapan sejumlah santri menyangkut ilmu agama. Setelah itu, kyai menggunakan pola komunikasi instruksional memerintahkan para santri untuk membuat sebuah naskah pidato dengan tema yang tidak ditentukan oleh pengajar, melainkan para santri dibebaskan untuk memilih tema sesuai dengan kemampuan yang dimilikinya.

Hal ini dimaksudkan agar mereka dibiasakan setiap minggunya untuk tampil membahas sebuah tema di hadapan orang lain. Karena muhadarah dilaksanakan secara terus menerus, maka sikap percaya diri dan keberanian tersebut akan muncul dengan sendirinya karena selalu diasah setiap minggunya.

Dalam pelaksanaannya, para santri dikumpulkan dalam sebuah ruangan (bila terjadi hujan) namun pada umumnya mereka dikumpulkan di sebuah tanah lapang, dengan laki-laki perempuan berbaris rapi secara terpisah, dan didukung oleh sebuah pengeras suara (speaker) untuk memperjelas sebuah materi yang mereka bawakan. Kyai akan menunjuk para santri secara acak untuk tampil di hadapan para teman-temannya. 
Sedangkan kyai tersebut akan memantau perkembangan para santri dengan memberi penilaian di antara mereka.

Kyai akan memberikan sebuah nilai khusus untuk untuk beberapa orang yang dinilai memiliki kemampuan dalam bidang ini dan menampilkannya dalam beberapa peringatan hari besar Islam di lingkungan Pesantren. Inilah maksud dari adanya pembinaan mental dalam program tersebut, yakni melatih keberanian para santri ketika tampil di hadapan orang banyak. Dan dikemudian hari mereka pastinya sudah tidak merasa canggung lagi untuk tampil di hadapan masyarakat dalam melaksanakan perannya sebagai penyebar pesan dakwah. Namun tidak semua santri dapat melaksanakan program ini dengan baik, karena masih terdapat para santri yang merasa malu untuk tampil di hadapan teman-temannya.

Program ini sangat berguna bagi para santri karena dapat digunakan sebagai modal dasar mereka di masyarakat kelak. Program ini mempelajari tentang metode ataupun cara-cara membaca, dan menulis alQuran. Kegiatan dilakukan di dalam kelas dengan kyai memberikan ceramah dan santri mendengarkan. Bila pembahasan telah selesai, maka sudah tentu sang kyai akan memberikan latihan-latihan sesuai dengan materi yang telah dibahas tadi. Pola komunikasi yang digunakan dalam pelaksanaan program ini adalah pola komunikasi kelompok dengan kyai memberikan ceramah materi dan sejumlah santri mendengarkannya.

Dalam program inipun terdapat pola komunikasi instruksional, seperti memberikan laihan-latihan kepada para santri sesuai dengan materi yang telah dibahas. Pola pembinaan ini dilakukan dengan maksud agar para santri dapat memahami ilmu secara mendalam baik melalui materi dan tugas atau bahkan buku-buku pedoman yang diberikan oleh pengajar.

Pola komunikasi yang dilakukan dirasa cukup untuk menambah wawasan dan pengetahuan mereka. Karena untuk mencari dan menambah pengetahuan yang tidak didapatkan oleh mereka dari seorang kyai, tidak menutup kemungkinan mereka akan mencari sendiri melalui buku-buku pedoman lainnya. Dan ini akan menambah minat mereka 
A Ramdan, M. Usman.

untuk mendalami sendiri kekurangan yang dimilikinya dalam hal mambaca, dan menulis al-Qur'an.

Pelatihan seni baca al-Qur'an ini adalah pengembangan keterampilan para santri dalam membaca al-Qur'an. Pelatihan ini dimaksudkan sebagai penyokong kemampuan para santri saat terjun dalam masyarakat kelak. Dalam pelaksanaan program ini terdapat dua pola komunikasi yang digunakan, yaitu pola komunikasi kelompok dan pola komunikasi instruksional.

Pola komunikasi kelompok dilaksanakan dengan kyai memberikan contoh bacaan dengan menggunakan salah satu lagam dalam seni baca al-Qur'an dan kemudian sejumlah santri mengikuti secara bersama-sama dan terus berulang berkali-kali. Adapula pola instruksional dengan memberikan kesempatan kepada para santri untuk mencoba kemampuan mereka dalam membaca ayat demi ayat yang baru dicontohkan oleh kyainya.

Kedua pola tersebut memiliki maksud dan tujuan yang berbeda. Pola komunikasi kelompok dimaksudkan agar para santri dapat mengetahui dan memahami tentang tata cara dalam melantunkan ayat suci al-Qur'an berdasarkan contoh dan ulasan yang disampaikan oleh pengajar. Sedangkan pola komunikasi instruksional dilakukan dengan maksud agar para santri tidak hanya paham dari sudut pandang teori saja melainkan juga dari praktekikum tiap-tiap individu santri.

Pelatihan yang dilakukan sudah sangat cukup untuk memenuhi kebutuhan para santri dalam belajar seni baca al-Qur'an. Karena diharapkan mereka akan mendapatkan wawasan dari segi teori dan tata caranya. Dan mereka akan mendapatkan sebuah pemahaman dan pengalaman dalam melaksanakan kegiatan seni baca al-Qur'an. Sehingga akan memunculkan keberanian untuk mempraktekkannya secara individu di masyarakat.Program ini dilaksanakan pada waktu ba' da solat ashar.

Dan para santri dikumpulkan dalam sebuah posisi duduk yang telah diatur sedemikian rupa dengan posisi laki-laki dan perempuan terpisah. 
Dalam pelaksanaannya, para santri diwajibkan mengikuti dan mendengarkan penjelasan dari ustadz yang bertugas mengajar program ini.

Program ini dilaksanakan sebagai ilmu tambahan bagi para santri khususnya dari segi ilmu agama. Dalam pelaksanaannya, ubudiyah adalah pemberian materi dan praktikum ilmu fiqih.

Adapun pola komunikasi yang dilakukan oleh Pesantren Sirnarasa dalam pelaksanaan program ubudiyah ini adalah pola komunikasi kelompok berdasarkan panduan buku pedoman Kiyai bertatap muka dengan sejumlah santri melalui metode ceramah, kyai berusaha memberikan penjelasan atau ceramah kepada para santri tentang sebuah materi dan terdapat pula pola instruksional dalam program ini yakni kyai memerintahkan para santri untuk menghafal dan memeraktekkannya secara individual.

Hal ini dimaksudkan agar para santi dapat memahami secara mendalam dari segi materi maupun pelaksanaannya. Dan pola tersebut sangat cocok untuk meningkatkan pemahaman santri terhadap sebuah materi dalam hal fiqih tidak hanya dalam teori namun juga dari segi penerapan atau pelaksanaannya dalam kehidupan sehari-hari.

Adapun pelaksanaan dalam program mulok ini adalah mereka (santri) dikumpulkan dalam sebuah ruangan. Program ini dibagi menjadi dua sesi waktu pelaksanaan, untuk minggu ke-1 dan ke-2 adalah kyai akan memberikan penjelasan secara gambalng mengenai materi fiqih tertentu. Sedangkan minggu ke-3 adalah pelaksanaan hafalan bagi para santri secara individual atau lebih dikenal dengan istilah setoran.

Metode pembelajaran atau pembinaan sangat diperlukan pula untuk melancarkan proses penyampaian ilmu dari kyai kepada santri-nya. Karena, metode penyampaian turut menentukan keberhasilan suatu proses belajar mengajar dan tentunya didukung pula dengan pola komunikasi yang baik pula. Adapun beberapa metode yang dilakukan dalam pelaksanaan proses kegiatan belajar mengajar di Pesantren Sirnarasa ini adalah metode ceramah, diskusi, dan praktek. 
A Ramdan, M. Usman.

Metode ini mayoritas menggunakan lisan oleh para pengajar untuk menyampaikan materi kepada santri. Metode ceramah dapat berupa pidato (rethorika), khutbah, mengajar, dan sebagainya. Kelebihan dari metode ini adalah sifatnya yang fleksibel artinya mudah disesuaikan dengan situasi dan kondisi.

Maksudnya bila waktu mencukupi maka materi akan tersaji secara luas namun bila memiliki keterbatasan waktu, maka kajian materi akan dipersingkat namun tetap fokus pada inti pembelajaran. Kelemahan dari metode ini adalah kurang efektifnya pemahaman para santri terhadap materi secara mendalam dikarenakan metode tersebut bersifat satu arah.

Metode ini mendorong para santri untuk dapat aktif dan bersungguhsungguh dalam memperhatikan dan menguasai materi yang diberikan sehingga diharapkan para santri dapat lebih memahami persoalan yang dihadapinya. Metode ini memerintahkan para santri untuk dapat menguasai materi tanpa harus melihat buku pedoman.

Metode ini dilaksanakan untuk melatih dan memunculkan rasa percaya diri dan keberanian para santri dalam menjalankan kegiatan yang diikuti oleh mereka. Selain itu, metode ini berusaha untuk membiasakan para santri untuk senantiasa mengasah kemampuannya dalam mengembangkan diri untuk lebih memahami dalam penerapan berbagai ilmu yang telah didapatkannya.

Metode membaca ini dilakukan oleh kyai pada saat ia menyampaikan materi berdasarka pedoman yang ada. Kyai berposisi sebagai penyampai pesan dan santri mendengarkan.Sedangkan metode menyimak ini dilakukan oleh kyai untuk mengetahui tingkat pemahaman para santri saat mereka ditugaskan untuk membaca secara individual.

Pola komunikasi yang dilakukan di Pesantren Sirnarasa adalah:

Pertama Pola komunikasi interpersonal (antar pribadi) dilakukan dalam proses kegiatan belajar mengajar. Ada saatnya para santri berkonsultasi secara langsung kepada kyai ketika tidak mengerti dan merasa kesulitan dalam mengikuti beberapa program tersebut. Komunikasi antar pribadi ini terjadi saat di dalam maupun di luar jam belajar. Bentuk komunikasi 
ini dapat membantu kyai dalam meningkatkan semangat belajar kepada para santri-nya.

Kedua Pola komunikasi kelompok kecil dalam proses belajar mengajar di Pesantren Sirnarasa ini dapat terjadi saat kyai menyampaikan materi kepada para santri di dalam pelaksanaan sebuah program. Programprogram Pesantren ini mayoritas dilakukan di dalam ruangan, dan massa yang berada di dalam ruangan tersebut dapat dikatakan sebagai kelompok kecil.

Dalam proses komunikasi melalui pola komunikasi ini, kyai selalu memperhatikan umpan balik dari santrinya. Penyampaian dengan komunikasi verbal yang dilakukan oleh kyai diharapkan dapat memberikan hasil maksimal dengan kualitas pemahaman para santri yang mencukupi. Keuntungan yang dapatkan saat pengajar menggunakan pola komunikasi kelompok ini adalah kyai dapat menguasai situasi dan mengetahui tanggapan para santri saat menerima materi-materi yang telah diberikan.

Ketiga komunkasi instruksional Dengan banyaknya pemberian tugastugas latihan atau hafalan, maka saat itulah para pengajar menggunakan pola komunikasi instruksional. Dengan tujuan untuk mengetahui sejauh mana pemahaman para santri terhadap sebuah materi. Sehingga para santri tidak hanya memahami materi dari segi teori saja melainkan juga pelaksanaan-nya. Adapun beberapa macam instruksi yang diberikan oleh pengajar kepada para santri, antara lain: a) Santri diharuskan menghafal bait demi bait dalam program kajian kitab kuning. B) Santri diwajibkan untuk membaca dan mengikuti materi yang dijelaskan oleh pengajar seperti dalam program kajian kitab kuning dan program seni baca alQur'an. C) Santri diharuskan dapat berbicara dalam bahasa Arab saat program muhadatsah berlangsung. D) Santri diharuskan untuk berani tampil secara individual dan berpidato saat program muhadarah. E) Secara umum santri diwajibkan untuk mengikuti setiap kegiatan proses belajar mengajar sebagai perhitungan faktor penilaian selama aktif di Pesantren Sirnarasa. 
A Ramdan, M. Usman.

\section{Faktor Pendukung dan Penghambat Interaksi dan Komunikasi Kiyaii Terhadap Santri di Pesantren Sirnarasa}

Interaksi dan komunikasi dikatakan efektif ketika telah dicapai ketepatan, kesepakatan dan tujuan yang sama antara komunikator dan komunikan. Dalam kegiatan komunikasi sering terjadi beberapa masalah atau problem pendukung dan penghambat dalam hal penyampian pesan maupun penerimaan pesan, diantaranya sebagai berikut:

\section{Faktor Pendukung}

Faktor penunjang peran interaksi dan komunikasi kiyai-santri dalam peningkatan pemahaman santri di Pesantren Sirnarasa adalah adanya keakraban kyai dengan santri yang menjadikan proses berinteraksi menjadi lebih nyaman, dan santri pun dapat lebih mudah memahami apa yang disampaikan kyai. Jadi dalam memberikan pemahaman kyai tidak ada rasa canggung, begitu juga dengan santri, apabila santri belum paham maka santri tidak takut atau canggug dalam bertanya kepada kyai.

Sikap terbuka kyai dalam berkomunikasi kepada santri tanpa ada yag disembunyikan. Antara kyai dan santri mempunyai sikap keterbukaan yang mendukung terciptanya efektifitas komunikasi interpersonal yang ada di Pesantren Sirnarasa. Adanya sikap mendukung antara kyai dan santri untuk terciptanya komunikasi interpersonal di Pesantren Sirnarasa, hal ini membuat semakin akrab antara kyai dan santri dalam berkomunikasi dan dalam belajar mengajar, sehingga santri dalam menerima pelajaran atau materi dari kyai akan lebih bersemangat dan lebih mudah memahami.

Jadwal kegitan yang tertib juga menjadi pendukung kegiatan komunikasi di Pesantren Sirnarasa. Pelaksanaan kegiatan berdasarkan jadwal yang sudah ditentukan oleh pihak Pesantren dapat dilaksanakan secara baik sesuai dengan prosedur yang ada. Tingkat kedislipinan santri dapat dikatakan baik, dimana santri dapat melaksanakan kegiatan berdasarkan jadwal secara tertib. Ketertiban melaksanakan kegiatan, tanpa ada rasa keterpaksaan dapat menjadikan santri lebih cepat paham terhadap materi 
yang disampaikan kyai, dari situlah peran kyai terhadap santri dalam berinteraksi dan komunikasi.

\section{Faktor Penghambat}

Faktor penghambat dalam berinteraksi dan komunikasi di Pesantren Sirnarasa adalah sebagai berikut:

Di Pesantren Sirnarasa kyai menganggap santri ada yang cepat dan lambat dalam berinteraksi dan komunikasi dikarenakan rasa malu terhadap kyai. Sedangkan dari pihak santri, santri beranggapan kyai dalam memberikan suatu pemahaman atau materi ada yang mudah dipahami dan ada yang sulit untuk dipahaami. Hal ini menyebabkan santri merasa bingung, dan menjadikan suasana yang tidak menyenangkan bagi santri yang lambat dalam memahami hal tersebut. Sehingga interaksi dan komunikasi yang terjadi menjadi kurangefektif.

Dalam memberikan materi kepada santri, terkadang bahasa yang digunakan kyai mempunyai banyak makna dan santri salah dalam memahami makna tersebut. Hal ini yang menyebabkan komunikasi antara kyai dan santri tidak efektif. Dan menjadi hambatan dalam berkomunikasi antara kyai dan santri, karena tujuan dari komunikasi tidak tercapai.

Sikap kedewasaan santri yang kurang menjadikan penyebab komunikasi tidak efektif. Sehingga timbullah salah pemahaman dalam menerima pesan yang disampaikan kyai kepada santri

Kurang akrabnya antara santri dan keluarga kyai menajadikan interaksi dan komunikasi yang kaku.

\section{PENUTUP}

Penutup Dari uraian diatas dapat simpulkan sebagai berikut:

Pola interaksi dan komunikasi kyai terhadap santri di Pesantren Sirnarasa, sudah terbentuk secara aktif. Pola yang diterapkan oleh $\mathrm{KH}$. Muhammad Abdul Gaos Saefulloh Maslul terhadap santrinya adalah pola komunikasi verbal, intruksional, personal dan intrapersonal. Dalam hal ini, kyai dan santri berperan sebagai komunikator dan komunikan. 
A Ramdan, M. Usman.

Kedekatan antara keduanya semakin intens ketika interaksi sosial mulai diterapkan.

Pengaruh interaksi dan komunikasi kyai terhadap santri di pesantren sirnarasa sangat terasa. Santri mulai mengikuti prilaku kyainya sehingga tercermin akhlak yang baik. Hasilnya santri dapat berkomunikasi dengan baik dan benar kepada semua orang, akhlak santri semakin meningkat yang ditandai dengan sikap khidmat, dan ta'dzim kepada Kiyai beserta keluarga besar Pesantren Sirnarasa, dan santri semakin memahami dan mematuhi peraturan-peraturan sebagaimana yang telah diterapkan oleh Pesantren Sirnarasa sehingga kegiatan rutinitas santri Pesantren Sirnarasa terkoordinir dengan baik.

Fakor Pendukung interaksi dan komunikasi Kiyai terhadap santrinya di Pesantren sirnarasa bisa sukses, dikarenakan: keakraban kyai yang ditunjukan kepada santri sehingga santri merasa lebih akrab, sikap terbuka Kiyai dalam berkomunikasi, serta jadwal kegitan yang tertib mengakibatkan interaksi dan komunikasi lebih tepat dan efisien karena sesuai dengan waktunya. Sedangkan faktor penghambat dalam interaksi dan komunikasi di Pesantren Sirnarasa diantaranya: kyai menggunakan komunikasi non verbal yang sulit dimengerti, sehingga santri sulit untuk menerjemahkan apa yang diisyaratkan Kiyai; sikap dari sebagaian keluarga Pesantren yang kurang akrab dengan santri menjadikan santri minder dalam bergaul bersama keluarga Pesantren Sirnarasa; serta pandangan santri terhadap kyai yang terlalu berlebihan karena keluhuran derajat atau posisi, yang akan mengakibatkan santri merasa malu untuk bertanya.

\section{DAFTAR PUSTAKA}

Asnawir dan Basyaruddin Usman.2002. Media Pembelajaran, Jakarta: Ciputat Press.

Abudin Nata (ed). 2001. Sejarah Pertumbuhan dan Perkembangan Lembaga-Lembaga Pendidikan Islam di Indonesia, Jakarta: Grasindo. 
Ali bin Haji Mohammed. 2011. Sitem dan Pola Pendidikan Sufi, Tasikmalaya: Mudawwamah Warohmah.

Abdul Qadir Djaelani. 1994. Peran Ulama dan Santri dalam Perjuang Politik Islam di Indonesia, Surabaya: Bina Ilmu.

Alisuf Sabri. 2005. Pengantar Ilmu Pendidikan, Jakarta: UIN Jakarta.Asnawir dan Basyaruddin Usman. 2002. Media Pembelajaran, Jakarta: Ciputat Press.

Amin Haedari, dkk. 2004. Masa Depan Pesantren dalam Tantangan Modernitas dan Tantangan Komplesitas Global, Jakarta: IRD Press.

Departemen Agama RI, 1998. Al-Quran dan Terjemah, Surabaya: AlHidayah.

Deddy Mulyana. 2002. Ilmu Komuniksi Suatu Pengantar, Bandung: Remaja Rosdakarya.

Dani Vardiansyah. 2004. PengantarIlmu Komunikas, Jakarta: Ghalia Indonesia.

Fatah, H Rohadi Abdul, Taufik, M Tata, Bisri, Abdul Mukti. 2005. Rekontruksi

Muis. 2001. Komunikasi Islam, Bandung: Remaja Rosdakarya. Pesantren Masa Depan, Jakarta Utara: Listafariska Putra.

Haedari, H.Amin. 2007. Transformasi Pesantren, Jakarta: Media Nusantara.

Hasbullah. 1996. Sejarah Pendidikan Islam Di Indonesia, Jakarta: RajaGrafindo Persada.

Mas'ud, Abdurrahman. 2004. Intelektual Pesantren Perhelatan Agama dan Tradisi. Yogyakarta: LKIS.

Onong Uchjana Effendy. 1993. Dinamaika Komunikasi, Bandung: Remaja Rosdakarya.

Zamakhsyari Dlofier. 1985. Tradisi Pesantren, Jakarta: LP3S 